\title{
Effect of 17ß-estradiol on hypothalamic GnRH-II gene expression in the female rhesus macaque
}

\author{
V S Densmore and H F Urbanski \\ Division of Neuroscience, Oregon National Primate Research Center, 505 NW 185th Avenue, Beaverton, Oregon 97006, USA \\ (Requests for offprints should be addressed to H F Urbanski; Email: urbanski@ohsu.edu)
}

\begin{abstract}
The hypothalamus of rhesus macaques expresses two molecular forms of gonadotropin-releasing hormone $(\mathrm{GnRH}-\mathrm{I}$ and $\mathrm{GnRH}-\mathrm{II})$. However, it is unclear whether these two neuropeptides play similar roles in the control of reproductive neuroendocrine function, especially in the context of positive and negative estrogen feedback. To address this issue, in situ hybridization histochemistry was used to compare the effect of $17 \beta$-estradiol $(\mathrm{E})$ on the expression of $\mathrm{GnRH}-\mathrm{I}$ and $\mathrm{GnRH}$-II mRNA in the medial basal hypothalamus $(\mathrm{MBH})$ of adult female macaques. GnRH-I mRNA expression was found to be significantly $(P<0.01)$ more abundant in ovariectomized (ovx) animals compared with ovariectomized E-treated (ovx $+E)$ animals. In marked contrast, GnRH-II mRNA expression was found to be significantly $(P<0.05)$ more abundant in ovx $+\mathrm{E}$ animals than in the ovx animals. To help elucidate how $\mathrm{E}$ exerts this stimulatory action on $\mathrm{GnRH}-\mathrm{Il}$ gene expression, hypothalamic sections were subsequently double labeled using a combination of immunohistochemisty for estrogen receptor (ER) $-\alpha$ or $-\beta$ and in situ hybridization histochemistry for $\mathrm{GnRH}-\mathrm{Il}$. Approximately $50 \%$ of the $\mathrm{GnRH}-\mathrm{Il}$ positive cells in the $\mathrm{MBH}$ were found to express $E R \beta$, but none expressed ER $\alpha$. Taken together, these data give credence to a novel pathway by which $\mathrm{E}$ may control the primate neuroendocrine reproductive axis, one that involves stimulation of $\mathrm{GnRH}-I I$ release via an ER $\beta$-mediated mechanism.
\end{abstract}

Journal of Molecular Endocrinology (2004) 33, 145-153

\section{Introduction}

It has recently been demonstrated that a second form of gonadotropin-releasing hormone $(\mathrm{GnRH})$, called chicken-II GnRH or GnRH-II, is expressed in the central nervous system of many mammalian species including some primates (Krey et al. 1975, Kasten et al. 1996, Dellovade et al. 1993, Chen et al. 1998, White et al. 1998, Urbanski et al. 1999). GnRH-II (pGlu-His-Trp-Ser-His-Gly-Trp-TyrPro-Gly-NH2) differs by only three amino acids from the traditional mammalian form of $\mathrm{GnRH}$ (GnRH-I; pGlu-His-Trp-Ser-Tyr-Gly-Leu-ArgPro-Gly-NH2), but is encoded by a different gene (White et al. 1998) and is expressed by a distinct population of cells (Latimer et al. 2001). Moreover, GnRH-II has been detected in representative members of almost every extant vertebrate class, and its sequence is the most phylogenetically conserved of all the known GnRH forms (Miyamoto et al. 1984, Powell et al. 1986, Yu et al.
1988, Muske et al. 1990, Lovejoy et al. 1992, Krajewsk et al. 2003). Although the physiological function of GnRH-II in vertebrates is unclear, its close structural similarity to GnRH-I suggests that it too may be a key component of the reproductive neuroendocrine axis.

Several issues remain unresolved in the field of primate reproductive neuroendocrinology, especially those pertaining to the control of puberty and the generation of the pre-ovulatory gonadotopin surge (Plant et al. 1978, Karsch 1987, Gore et al. 1993, Pau et al. 1993, Ma et al. 1994, Mitsushima et al. 1994, Kasten et al. 1996, Kasuya et al. 1999, El Majdoubi et al. 2000). Indeed, it is still equivocal whether enhanced GnRH-I release plays a fundamental role in triggering the pre-ovulatory gonadotropin surge. On the other hand, it has recently been demonstrated that GnRH-II is highly expressed in the rhesus macaque medial basal hypothalamus $(\mathrm{MBH})$; this brain region has been implicated in both the pre-ovulatory surge (Spies 
et al. 1977) and reproductive development (Khorram et al. 1988, Gore et al. 1993). Further, in gonad-intact rhesus macaques hypothalamic expression of GnRH-I mRNA does not increase significantly during pubertal development, whereas the expression of GnRH-II mRNA does, at least within the MBH (Latimer et al. 2000). Although this developmental increase in GnRH-II gene expression could play an important role in triggering puberty, it is equally plausible that the increase simply reflects a positive influence of estrogen on GnRH-II expression, and so represents a consequence of pubertal development rather than a cause. Nevertheless, the demonstration that GnRH-II is a potent stimulator of gonadotropin release in vivo (Lescheid et al. 1997, Densmore et al. 2003) further underscores the possibility that GnRH-II is physiologically involved in controlling the reproductive axis of primates.

In the present study, we used in situ hybridization histochemistry to compare GnRH-II mRNA levels in two groups of females: ovariectomized (ovx) and ovariectomized with $17 \beta$-estradiol replacement $(\mathrm{ovx}+\mathrm{E})$. In addition, we used in situ hybridization histochemistry combined with immunohistochemistry to examine whether hypothalamic GnRH-IIexpressing cells also express estrogen receptors, and thereby have the capacity to respond directly to changes in the sex-steroid environment. Preliminary findings have already been published as an abstract (Latimer \& Urbanski 2002).

\section{Materials and methods}

\section{Animals}

This study was performed in vitro on hypothalami from adult (6-12 years old) female rhesus macaques (Macaca mulatta), obtained through the Oregon National Primate Research Center (ONPRG) Tissue Distribution Program; other tissues from these animals were used in unrelated studies. Prior to necropsy, animal care was provided in accordance with the NIH Guide for the Care and Use of Laboratory Animals, and with approval of the ONPRG Animal Care and Use Committee. The animals were housed under controlled lighting (12 h light:12 h darkness) and temperature $\left(23 \pm 2{ }^{\circ} \mathrm{C}\right)$, and were provided with a diet consisting of Purina monkey chow and fresh fruit, with unlimited access to drinking water.
In Experiment 1, six ovariectomized animals were used to examine the influence of $17 \beta$-estradiol (E) on GnRH-I and GnRH-II gene expression; the ovariectomies were performed at least 1 month prior to necropsy. Three of these animals served as untreated controls (ovx), while three received E replacement immediately after ovariectomy $(\mathrm{ovx}+\mathrm{E})$; in the latter group, silastic capsules containing crystallized E (Sigma) were implanted subcutaneously, as previously described (Gundlah et al. 2000) and this restored serum E concentrations (determined by RIA) to $\sim 60 \mathrm{pg} / \mathrm{ml}$, which is within physiological parameters for the ovaryintact adult rhesus macaque (Karsch 1987). For reference, three gonad-intact females were also included in the study; at the time of necropsy, two of these were in the early-follicular phase of their menstrual cycle and one was in the luteal phase.

In Experiment 2, hypothalami from three adult gonad-intact females were used to examine whether GnRH-II cells express estrogen receptors. Based on detailed menstruation records, one of these animals was in the early-follicular phase of the menstrual cycle and the other two were in the luteal phase.

\section{Tissue preparation}

The animals were deeply anesthetized using ketamine/pentobarbital according to procedures established by the Panel on Euthanasia of the American Veterinary Society. Their brains were fixed by perfusing $110.9 \%$ saline through the ascending aorta followed by 6.51 ice-cold $4 \%$ paraformaldehyde in $0.1 \mathrm{~mol} / \mathrm{l}$ phosphate-buffered (pH 7.6) saline $(0.9 \%, \mathrm{w} / \mathrm{v})$. The hypothalami were blocked just rostral to the optic chiasm and rostral to the mammillary bodies, and immersed in fresh fixative for an additional $3 \mathrm{~h}\left(\right.$ at $\left.4{ }^{\circ} \mathrm{C}\right)$. They were then cryoprotected and sectioned $(25 \mu \mathrm{m})$ in the coronal plane using a freezing sliding microtome, as previously described (Latimer et al. 2001). For Experiment 1, the sections were immediately mounted on glass microscope slides (Fisherbrand SuperFrost/Plus, Fisher Scientific, Auburn, WA, USA), air-dried for $30 \mathrm{~min}$, vacuum-dried overnight, and then stored at $-85^{\circ} \mathrm{C}$ for later use in in situ hybridization histochemistry. For Experiment 2 , the hypothalamic sections were stored freefloating in cryoprotectant at $-20{ }^{\circ} \mathrm{C}$ (Latimer et al. 2001), and subsequently used within 6 months for 
combined immunohistochemistry and in situ hybridization histochemistry.

\section{Experiment 1: effect of E on GnRH-I and GnRH-Il gene expression}

In situ hybridization histochemistry was used to determine the effect of $\mathrm{E}$ on GnRH gene expression. The procedure involved the use of previously validated ${ }^{35}$ S-labeled antisense riboprobes to rhesus macaque GnRH-I mRNA or rhesus macaque GnRH-II mRNA (Ma et al. 1994, Urbanski et al. 1999, Latimer et al. 2001). These riboprobes were 224- or 430-nucleotides long respectively, and spanned the complete decapeptide-coding region as well as most of the GnRH-associated peptide (GAP) coding region. Because the GAP-coding region is unique for each GnRH precursor form, the probes specifically identified only those cells that express GnRH-I or GnRH-II mRNA respectively. The in situ hybridization histochemistry was performed, as described previously (Latimer et al. 2001), on a series of six coronal hypothalamic sections from each animal; the sections were collected at $200 \mu \mathrm{m}$ intervals. To examine regional mRNA distribution at the cellular level, the sections were subsequently dehydrated using increasing concentrations of ethanol, defatted in xylenes for $1 \mathrm{~h}$, and dipped in photographic emulsion (NTB-2, Eastman Kodak Co., Rochester, NY, USA) to induce silver grain deposition. They were exposed at $4{ }^{\circ} \mathrm{C}$ in a light-tight box for 12 days and then processed with Kodak developer (D-19) and fixer. Next, the sections were washed for $5 \mathrm{~min}$ in distilled water and dipped in thionine (Sigma) for $10 \mathrm{~min}$, followed by two 5-min washes in water. The sections were then dehydrated with ethanol, cleared with xylenes, and finally coverslipped using DPX mounting medium.

A previous GnRH-II in situ hybridization study demonstrated that silver grain deposition accurately reflects optical density of autoradiographs (Latimer et al. 2000), but gives better spatial resolution; therefore, in the present study silver grain density was preferentially analyzed as a semi-quantitative measurement of GnRH expression under the different sex-steroid environments. The hypothalamic sections were examined under both bright-field and dark-field microscopy using a $\times 40$ objective lens, and only cells that had an obvious round or fusiform silver grain deposition pattern surrounding a thionine-stained nucleus were included in the analysis. The images were digitized using a Sony XC-77 CCD camera (Sony Corp. of America, Cypress, CA, USA) equipped with a 50-mm macro lens, and analyzed using the NIH Image computer program (version 1.59). Individual cells were defined using the freehand outlining tool, and both the silver grain density per cell (expressed as pixels per cell) and the total number of positive cells per section were determined. Unlike GnRH-II, GnRH-I is not expressed in distinct hypothalamic nuclei (Latimer et al. 2001); therefore, the mean level of GnRH-I expression across the whole hypothalamus was analyzed. In contrast, GnRH-II expression was analyzed for individual hypothalamic nuclei/regions. Two-way ANOVA was used to assess statistical differences between the treatment groups, and post-hoc analysis was performed using Newman-Keuls, when appropriate.

\section{Experiment 2: expression of estrogen receptors in GnRH cells}

We have previously observed estrogen receptor (ER)- $\beta$ mRNA expression in regions of the macaque hypothalamus where GnRH-II mRNA is also expressed (Urbanski et al. 1999, Gundlah et al. 2000, Latimer et al. 2000,2001). To examine whether there is co-localization of expression, we now collected 8-12 hypothalamic sections $(25 \mu \mathrm{m}$ thick) at $\sim 200 \mu \mathrm{m}$ intervals from each animal, and processed them for immunohistochemistry (for $\mathrm{ER} \beta$ ) followed by in situ hybridization histochemistry (for GnRH-II mRNA). The solutions for both of these procedures were made using RNase-free, diethyl pyrocarbonate-treated water. First, the sections were washed three times, $5 \mathrm{~min}$ each, with Tris buffer $(0 \cdot 05 \mathrm{M}$ Tris, $\mathrm{pH} 7 \cdot 6$, containing $0 \cdot 15 \mathrm{M}$ sodium chloride). They were then incubated overnight at $4{ }^{\circ} \mathrm{C}$ with previously characterized antibodies (Russell et al. 2000, Saunders et al. 2000, Gundlah et al. 2001) to either ER $\alpha$ (Santa Cruz Biotech, Santa Cruz, CA, USA) or ER $\beta$ (a gift from Dr P T K Saunders) at 1:800 dilution in Tris buffer containing an RNase inhibitor (1 IU/ml; Promega). The sections were then washed three times, 5 min each, incubated in biotinylated goat anti-sheep or horse anti-mouse IgG (Vector Laboratories, Burlingame, CA, USA) at 1:1000 dilution in Tris buffer for $1 \mathrm{~h}$ at room 


\section{GnRH-I}
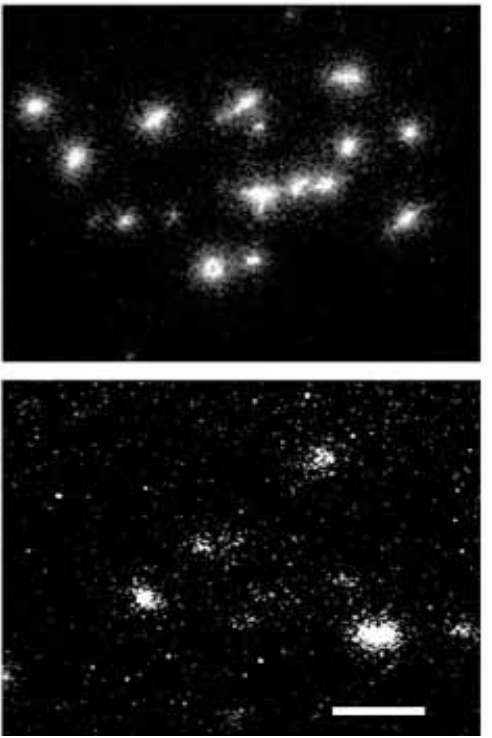

GnRH-II
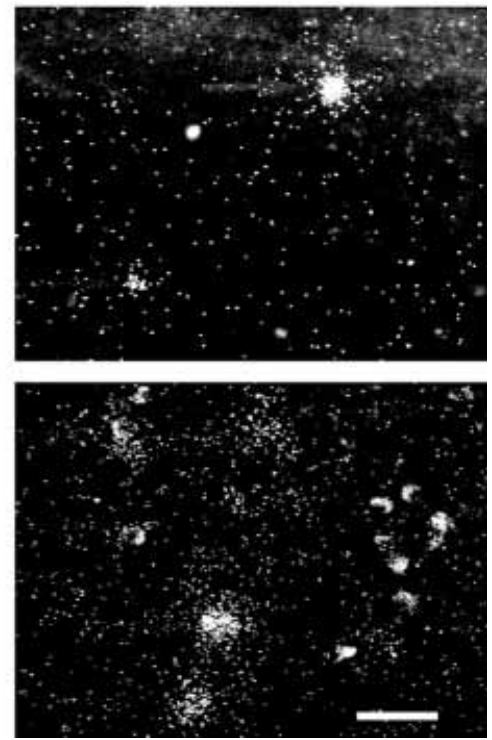

Figure 1 Effect of $17 \beta$-estradiol (E) replacement on $\mathrm{GnRH}$ gene expression in ovariectomized (ovx) rhesus macaques, as revealed by isotopic in situ hybridization histochemistry. Left column: Representative dark-field photomicrographs demonstrating a marked decrease in hypothalamic GnRH-I mRNA levels after $\mathrm{E}$ replacement. Right column: Representative dark-field photomicrographs demonstrating a marked increase after $E$ replacement. Scale bar $=15 \mu \mathrm{m}$.

temperature, and again washed. To detect the immunoreactive signal, the sections were exposed to an avidin/biotin complex (Standard ABC kit, Vector Laboratories) for $1 \mathrm{~h}$, washed three times in Tris buffer, $5 \mathrm{~min}$ each, and exposed to 3,3'diaminobenzidine tetrachloride (DAB, $1 \mathrm{mg} / \mathrm{ml}$ Tris buffer; Sigma) for $10 \mathrm{~min}$, concluding with 3 more washes. The sections were then mounted on glass microscope slides (Fisherbrand; Fisher Scientific), air-dried for $30 \mathrm{~min}$, vacuum-dried overnight, and then stored at $-85^{\circ} \mathrm{C}$. The same sections were subsequently processed for in situ hybridization histochemistry using a ${ }^{35}$ S-labeled antisense riboprobe against GnRH-II precursor cDNA, as described above, except that no thioninecounterstaining was performed. Similarly, they were dehydrated, defatted, dipped in photographic emulsion, and the pattern of silver grain deposition was examined under both bright-field and darkfield microscopy. Only cells that had an obvious round or fusiform silver grain deposition pattern, and a silver grain density greater than five times the background level, were counted and analyzed.

\section{Results}

\section{E and GnRH-II gene expression}

The hypothalami from ovx animals expressed significantly $(P<0 \cdot 01)$ more GnRH-I mRNA than the hypothalami from ovx $+\mathrm{E}$ animals (Fig. 1 left column, and Fig. 2A). This increased level of GnRH-I mRNA expression was reflected as an increase in the number of cells expressing silver grains at a level five times above background. The hypothalami from ovx animals also expressed significantly $(P<0 \cdot 01)$ more GnRH-1 mRNA than hypothalami from the gonad-intact controls.

In marked contrast, the $\mathrm{MBH}$ from $\mathrm{ovx}+\mathrm{E}$ animals expressed significantly $(P<0.05)$ more GnRH-II mRNA than the MBH from ovx animals (Fig. 1 right column, and Fig. 2B); as with GnRH-I mRNA, the increased level of GnRH-II mRNA expression in the ovx $+\mathrm{E}$ animals was reflected as an increase in the total number of cells expressing silver grains at a level five times above background (Fig. 2B). It should be emphasized, however, that this differential expression of $\mathrm{GnRH}-\mathrm{II}$ in response 

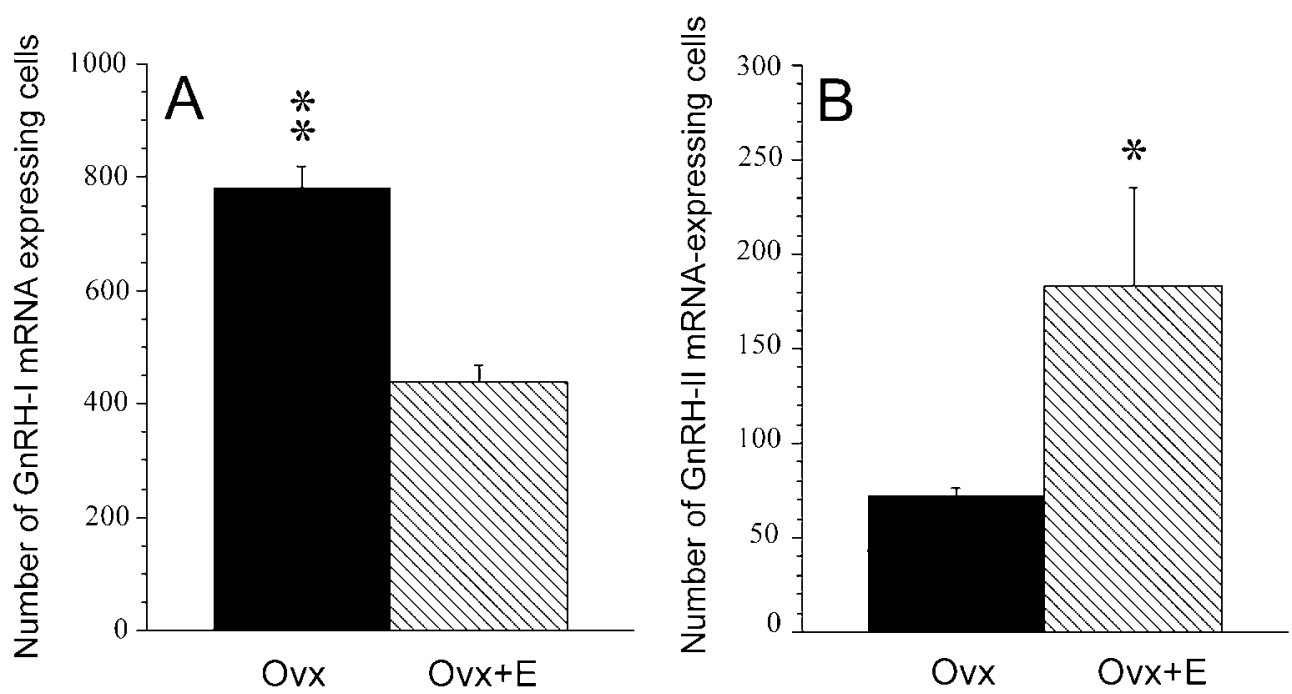

Figure 2 Effect of $E$ replacement on $G n R H$ gene expression in ovx rhesus macaques. (A) Histogram depicting number of cells expressing GnRH-I mRNA in the hypothalamus of ovx and ovx $+\mathrm{E}$ animals, as revealed by in situ hybridization histochemistry (Fig. 1, left column). The number of detectable GnRH-I cells in the hypothalamus was markedly lower in the ovx $+E$ animals than in the ovx animals. (B) Histogram depicting number of cells expressing GnRH-II mRNA in the MBH of ovx and ovx + E animals, as revealed by in situ hybridization histochemistry. The number of detectable $\mathrm{GnRH}-\mathrm{Il}$ cells in the $\mathrm{MBH}$ was markedly greater in the ovx $+\mathrm{E}$ animals than in the ovx animals. The in situ hybridization histochemistry was performed on a series of six coronal hypothalamic sections from each animal ( $n=3 /$ group); the sections were collected at $\sim 200 \mu \mathrm{m}$ intervals. For reference, the mean number of $\mathrm{GnRH}-\mathrm{I}$ - and $\mathrm{GnRH}-\mathrm{II}$-expressing cells detected in a heterogenous group of three gonad-intact animals (early-follicular phase and luteal phase) was $272 \pm 74$ and $41 \pm 5$, respectively. ${ }^{* *} P<0.01,{ }^{*} P<0.05$.

to $\mathrm{E}$ was observed only within the $\mathrm{MBH}$, and that no difference in GnRH-II mRNA expression was observed in the supraoptic nucleus (SON) and paraventricular nucleus (PVN), which served as negative controls (data not shown). Interestingly, the $\mathrm{MBH}$ from the heterogenous group of gonad-intact animals expressed significantly $(P<0 \cdot 01)$ less GnRH-II mRNA than the MBH from the ovx $+\mathrm{E}$ animals.

\section{Co-localization of estrogen receptors and GnRH-II mRNA}

Digitized microscopic images were used to identify $\mathrm{ER} \alpha$ or ER $\beta$ expression (visualized as DAB precipitate) in GnRH-II-expressing cells (positively labeled cells showed a silver grain density that exceeded five times the background level). Approximately $50 \%$ of the GnRH-II-expressing cells in the $\mathrm{MBH}$, and $40 \%$ in the PVN, showed immunoreactivity for $\mathrm{ER} \beta$ (Fig. 3, and Table 1). In contrast, no regional overlap between ER $\beta$ immunoreactivity and GnRH-II mRNA expression was evident in the SON. In addition, there was no detectable coexpression of GnRH-II and $\mathrm{ER} \alpha$ in any hypothalamic region (data not shown).

\section{Discussion}

In a previous study, using ribonuclease protection assay, E was found to decrease GnRH-I gene expression in the hypothalamus of ovariectomized rhesus macaques (El Majdoubi et al. 1998). A similar result was obtained using in situ hybridization histochemistry, in the ovariectomized cynomolgus macaque (King et al. 1994). The results from the present in situ hybridization study corroborate both of these findings, by showing that E can markedly attenuate the post-ovariectomy rise in hypothalamic GnRH-I gene expression. Moreover, the results are in harmony with those from a 


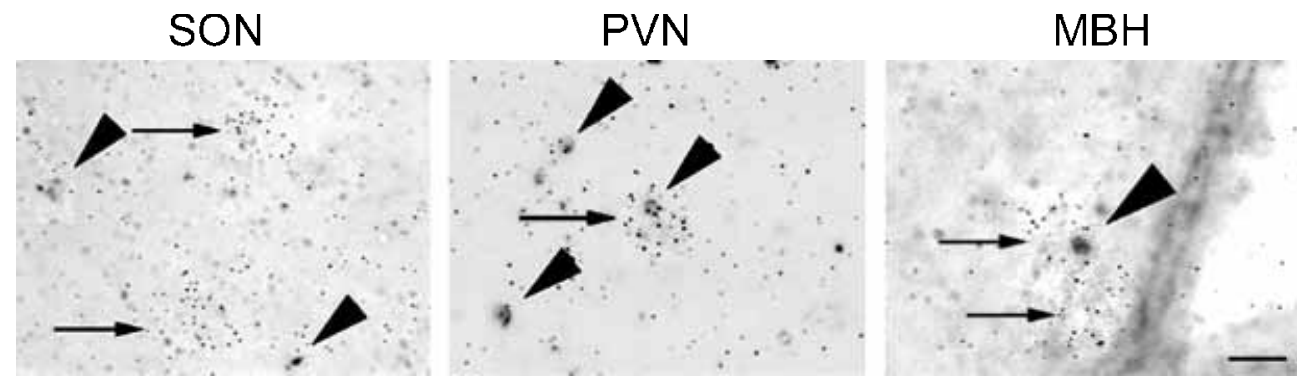

Figure 3 Representative photomicrographs of hypothalamic sections, double-labeled using a procedure that combined immunohistochemistry with in situ hybridization histochemistry. The sections were initially processed for ER $\beta$ immunohistochemistry and then for in situ hybridization histochemistry using a ${ }^{35} \mathrm{~S}$-labeled riboprobe to $\mathrm{GnRH}-\mathrm{II}$ mRNA. ER $\beta$-positive cells (showing nuclear staining) are indicated by arrowheads, and cells expressing $\mathrm{GnRH}-\mathrm{II}$ mRNA are identified by densely clustered silver grains, indicated by arrows. Note the coexpression of ER $\beta$ and $\mathrm{GnRH}-\mathrm{II}$ in the $\mathrm{MBH}$ and PVN but not in the SON. Scale bar=10 $\mu \mathrm{m}$.

human postmortem study (Rance \& Uswandi 1996) which showed that GnRH-I gene expression increases significantly in the $\mathrm{MBH}$ after menopause (i.e, when circulating $\mathrm{E}$ concentrations are extremely low or undetectable).

However, the present study is the first one to show that $\mathrm{E}$ can also effect GnRH-II gene expression in the $\mathrm{MBH}$ of a primate species. Surprisingly, unlike GnRH-I mRNA, GnRH-II mRNA levels were not suppressed after E replacement, instead they showed a marked increase. Indeed, the continuous delivery of exogenous $\mathrm{E}$ enhanced GnRH-II mRNA levels well above those observed in the gonad-intact animals (which were in the early-folliclular and luteal phase of their menstrual cycle, and so were exposed to lower endogenous E levels). Taken together, the

Table 1 Co-expression of ER $\beta$ in hypothalamic $\mathrm{GnRH}-\mathrm{II}$ cells

\begin{tabular}{|c|c|c|}
\hline & $\begin{array}{l}\text { Number of } \\
\text { ERß-positive } \\
\text { GnRH-Il cells }\end{array}$ & $\begin{array}{l}\text { Number of } \\
\text { ERß-negative } \\
\text { GnRH-Il cells }\end{array}$ \\
\hline \multicolumn{3}{|c|}{$\begin{array}{l}\text { Hypothalamic } \\
\text { nucleus }\end{array}$} \\
\hline SON & 19 (7\%) & $200(93 \%)$ \\
\hline PVN & $28(40 \%)$ & $51(60 \%)$ \\
\hline $\mathrm{MBH}$ & $41(50 \%)$ & $40(50 \%)$ \\
\hline
\end{tabular}

GnRH-positive cells were identified by in situ hybridization histochemistry. Values represent the total number of $\mathrm{GnRH}-\mathrm{Il}$ cells that were immuno-positive or immuno-negative for ER $\beta$ in the examined sections (6 sections per animal). The respective percentages are shown in parentheses. findings from the GnRH-I and GnRH-II in situ hybridization studies give credence to the existence of two independent hypothalamic GnRH neuronal systems (Latimer et al. 2001), which differ markedly in their response to E. They also add support to a previous suggestion (Latimer et al. 2000) that functionally-distinct subpopulations of GnRH-II neurons may exist in the primate hypothalamus. Two observations, in particular, support this conclusion. First, E affected GnRH-II expression specifically in the $\mathrm{MBH}$, but not in the PVN or SON, and secondly, $\sim 50 \%$ of GnRH-II cells in the $\mathrm{MBH}$ and $\sim 40 \%$ in the PVN expressed $\mathrm{ER} \beta$-immunoreactivity, whereas very little colocalization of GnRH-II and $\operatorname{ER} \beta$ was evident in the SON. The latter observation suggests that the SON population of GnRH-II cells may function independently of estrogen signaling, although it does not rule out a possible indirect influence via inhibitory or stimulatory neurotransmitters. Conversely, although nearly half the GnRH-II cells in the PVN were found to express ER $\beta$, GnRH-II gene expression in this nucleus did not appear to be affected by $\mathrm{E}$; however, it is unknown whether $\mathrm{E}$ can effect the translation or release of GnRH-II from the PVN.

This demonstration that $\mathrm{E}$ exerts variable effects on different GnRH-II cell populations in the primate is reflective of the variable data that have been reported for other vertebrate species. For example, E did not alter midbrain GnRH-II expression in either the cichlid (Oreochromis mossambicus) or European silver eel (Anguilla anguilla) 
(Montero et al. 1995, Parhar et al. 1996). Also, the breeding season had no affect on whole-brain GnRH-II expression in the seabream (Sparus aurata) (Holland et al. 1998) or rockfish (Sebastes rastrelliger) (Collins et al. 2001), and stage of development had no effect on midbrain GnRH-II expression in rainbow trout (Salmo gairdneri) (Okuzawa et al. 1990). However, photostimulated turkey hens (Meleagris gallopavo) showed an increase in hypothalamic GnRH-II peptide (Rozenboim et al. 1993), and adult female turtles (Trachemys scripta) showed an increase in GnRH-II peptide relative to hatchling females (Tsai \& Licht 1993). Also, African catfish (Clarias gariepinus) showed a developmental increase in GnRH-II immunoreactivity in the midbrain tegmentum (Dubois et al. 2001).

Interestingly, in the present study the most significant changes in GnRH-II gene expression were observed in the $\mathrm{MBH}$, a region that has been implicated in several reproductive events including the control of puberty, pulsatile gonadotropin release, and possibly the pre-ovulatory gonadotropin surge (Atkinson et al. 1970, Nakai et al. 1978, Plant et al. 1978, Knobil et al. 1980, Caraty et al. 1998, Walsh \& Clarke 1998, Kasuya et al. 1999, El Majdoubi et al. 2000, Plant 2001). This raises the provocative suggestion that GnRH-II may play a physiological role in the regulation of these events. Although this possibility remains to be substantiated experimentally, it gains support from the observation that GnRH-II is detectable in the systemic circulation of humans (Siler-Khodr \& Grayson 2001), and that GnRH-II can dramatically stimulate gonadotropin release in rhesus macaques in vivo (Lescheid et al. 1997, Densmore \& Urbanski 2003). In addition, we have previously reported that GnRH-II gene expression in the macaque $\mathrm{MBH}$ increases during development (Latimer et al. 2000). Although additional studies are needed to determine if this developmental increase is primarily driven by a sex-steroid independent mechanism, the present finding that $\mathrm{E}$ can stimulate GnRH-II gene expression in the $\mathrm{MBH}$ suggests that the developmental increase may simply be a response to the pubertal rise in circulating $\mathrm{E}$ concentrations (i.e., a consequence rather than a cause of puberty).

It is well accepted that $\mathrm{E}$ exerts negative feedback on pulsatile gonadotropin release, both at the hypothalamic and pituitary levels, and that $\mathrm{E}$ positive feedback is necessary for the pre-ovulatory gonadotropin surge to occur (Atkinson et al. 1970, Yamaji et al. 1972, Karsch et al. 1973, Keye \& Jaffe 1974, Spies \& Norman 1975, Nakai et al. 1978, Ferin et al. 1979). However, the mechanisms underlying this apparent switch from negative to positive feedback are less clear. There are several convincing demonstrations that pituitary sensitivity to $\mathrm{GnRH}-\mathrm{I}$ increases in primates following $36 \mathrm{~h}$ or more of E concentrations above 200 pg/ml (Yamaji et al. 1972, Ferin et al. 1979, King et al. 1995), and that a GnRH-I surge occurs prior to ovulation (Pau et al. 1993). Similarly, E negative feedback has also been demonstrated at the level of both the pituitary and the hypothalamus (Yamaji et al. 1972, Spies \& Norman 1975, Ferin et al. 1979, Witkin et al. 1991, King et al. 1995), whether or not a GnRH-I surge is necessary for a gonadotropin surge to occur. However, the recent finding of a second estrogen receptor, ER $\beta$ (Mosselman et al. 1996), supports the hypothesis that the negative feedback might occur through one system, via $\mathrm{ER} \alpha$, while a second system, employing ER $\beta$, may signal positive feedback (Ordog et al. 1998). Additional support for this hypothesis comes from the observation that $\mathrm{E}$ exerted a positive effect on a population of GnRH-II cells (in the $\mathrm{MBH}$ ) that were shown to express ER $\beta$, whereas neither a negative effect nor $\mathrm{ER} \alpha$ expression was observed in any of the GnRH-II cell populations. The present data that $\mathrm{E}$ treatment increased GnRH-II, but decreased GnRH-I, expression are also consistent with the hypothesis that E may exert alternate effects on different GnRH neural systems rather than switching from negative to positive feedback using a single system. Despite the provocative data suggesting that GnRH-II can exert an influence on some aspects of reproductive function, it remains to be proven that this influence is physiological. Furthermore, one cannot rule out the possibility that the primary physiological role of GnRH-II in primates involves an entirely different neuroendocrine system, unrelated to reproduction.

In summary, the results from the present study suggest that E can directly exert a positive influence on GnRH-II gene expression in the $\mathrm{MBH}$, whereas $\mathrm{E}$ primarily exerts an indirect negative influence on GnRH-I gene expression. This may help to explain why the net influence of $\mathrm{E}$ on the reproductive axis is negative when its concentration is below a certain threshold but positive when its concentration is higher; theoretically, a comprehensive 
dose-response study should be able to identify a concentration of $\mathrm{E}$ (and duration of exposure) that tips the scales in favour of one GnRH control system over the other. Overall, the present results are consistent with the view that reproductive function in primates is controlled by functionally distinct GnRH neuronal pathways, and that these pathways respond differentially to changes in the sex-steroid environment.

\section{Acknowledgements}

We wish to thank Dr Philippa T K Saunders at the MRG Human Reproductive Sciences Unit, Edinburgh, for generously providing us with the antibody to ER $\beta$. This research was supported by NIH Grants: RR00163, HD29186 and AG19100.

\section{References}

Atkinson LE, Bhattacharya AN, Monroe SE, Dierschke DJ \& Knobil E 1970 Effects of gonadectomy on plasma LH concentration in the rhesus monkey. Endocrinology 87 847-849.

Caraty A, Fabre-Nys C, Delaleu B, Locatelli A, Bruneau G, Karsch FJ \& Herbison A 1988 Evidence that the mediobasal hypothalamus is the primary site of action of estradiol in inducing the preovulatory gonadotropin releasing hormone surge in the ewe. Endocrinology 139 1752-1760.

Chen A, Yahalom D, Ben-Aroya N, Kaganovsky E, Okon E \& Koch Y 1998 A second isoform of gonadotropin-releasing hormone is present in the brain of human and rodents. FEBS Letters 435 199-203.

Collins PM, O'Neill DF, Barron BR, Moore RK \& Sherwood NM 2001 Gonadotropin-releasing hormone content in the brain and pituitary of male and female grass rockfish (Sebastes rastrelliger) in relation to seasonal changes in reproductive status. Biology of Reproduction 65 173-179.

Dellovade TL, King JA, Millar RP \& Rissman EF 1993 Presence and differential distribution of distinct forms of immunoreactive gonadotropin-releasing hormone in the musk shrew brain. Neuroendocrinology 58 166-177.

Densmore VS \& Urbanski HF 2003 Relative effect of gonadotropin-releasing hormone (GnRH)-I and GnRH-II on gonadotropin release. Fournal of Clinical Endocrinology and Metabolism 88 2126-2134.

Dubois EA, Zandbergen MA, Peute J, Bogerd J \& Goos HJ 2001 Development of three distinct GnRH neuron populations expressing two different GnRH forms in the brain of the African catfish (Clarias gariepinus). Fournal of Comparative Neurology 437 308-320.

El Majdoubi M, Sahu A \& Plant TM 1998 Effect of estrogen on hypothalamic transforming growth factor alpha and gonadotropin-releasing hormone gene expression in the female rhesus monkey. Neuroendocrinology 67 228-235.

El Majdoubi M, Sahu A, Ramaswamy S \& Plant TM 2000 Neuropeptide Y: A hypothalamic brake restraining the onset of puberty in primates. PNAS $976179-6184$.

Ferin M, Rosenblatt H, Carmel PW, Antunes JL \& Vande Wiele RL 1979 Estrogen-induced gonadotropin surges in female rhesus monkeys after pituitary stalk section. Endocrinology 104 50-52.
Gore AC, Mitsushima D \& Terasawa E 1993 A possible role of neuropeptide $\mathrm{Y}$ in the control of the onset of puberty in female rhesus monkeys. Neuroendocrinology 58 23-34.

Gundlah C, Kohama SG, Mirkes SJ, Garyfallou VT, Urbanski HF \& Bethea CL 2000 Distribution of estrogen receptor beta (ER beta) mRNA in hypothalamus, midbrain and temporal lobe of spayed macaque: continued expression with hormone replacement. Brain Research (Molecular Brain Research) 76 191-204.

Gundlah C, Lu NZ, Mirkes SJ \& Bethea CL 2001 Estrogen receptor beta (ERbeta) mRNA and protein in serotonin neurons of macaques. Brain Research (Molecular Brain Research) 91 14-22.

Holland MCH, Gothilf Y, Meiri I, King JA, Okuzawa K, Elizur A \& Zohar Y 1998 Levels of the native forms of GnRH in the pituitary of the gilthead seabream, Sparus aurata, at several characteristic stages of the gonadal cycle. General and Comparative Endocrinology 112394405.

Karsch FJ 1987 Central actions of ovarian steroids in the feedback regulation of pulsatile secretion of luteinizing hormone. Annual Review of Physiology 49 365-382.

Karsch FJ, Weick RF, Butler WR, Dierschke DJ, Krey LC, Weiss G, Hotchkiss J, Yamaji T \& Knobil E 1973 Induced LH surges in the rhesus monkey: strength-duration characteristics of the estrogen stimulus. Endocrinology 92 1740-1747.

Kasten TL, White SA, Norton TT, Bond CT, Adelman JP \& Fernald RD 1996 Characterization of two new preproGnRH mRNAs in the tree shrew: first direct evidence for mesencephalic $\mathrm{GnRH}$ gene expression in a placental mammal. General and Comparative Endocrinology 104 7-19.

Kasuya E, Nyberg CL, Mogi K \& Terasawa E 1999 A role of gamma-amino butyric acid (GABA) and glutamate in control of puberty in female rhesus monkeys: effect of an antisense oligodeoxynucleotide for GAD67 messenger ribonucleic acid and MK801 on luteinizing hormone-releasing hormone release. Endocrinology 140 705-712.

Keye WR Jr \& Jaffe RB 1974 Modulation of pituitary gonadotropin response to gonadotropin-releasing hormone by estradiol. Fournal of Clinical Endocrinology and Metabolism 38 805-810.

Khorram O, Pau KY \& Spies HG 1988 Release of hypothalamic neuropeptide $\mathrm{Y}$ and effects of exogenous NPY on the release of hypothalamic $\mathrm{GnRH}$ and pituitary gonadotropins in intact and ovariectomized does in vitro. Peptides 9 411-417.

King JA, Steneveld AA, Curlewis JD, Rissman EF \& Millar RP 1994 Identification of chicken GnRH II in brains of metatherian and early evolved eutherian species of mammals. Regulatory Peptides $\mathbf{5 4}$ 467-477.

King JA, Millar RP, Vallarino M \& Pierantoni R 1995 Localization and characterization of gonadotropin-releasing hormones in the brain, gonads, and plasma of a dipnoi (lungfish, Protopterus annectens). Regulatory Peptides 57 163-174.

Knobil E, Plant TM, Wildt L, Belchetz PE \& Marshall G 1980 Control of the rhesus monkey menstrual cycle: permissive role of hypothalamic gonadotropin-releasing hormone. Science $\mathbf{2 0 7}$ $1371-1373$

Krajewski SJ, Abel TW, Voytko ML \& Rance NE 2003 Ovarian steroids differentially modulate the gene expression of gonadotropin-releasing hormone neuronal subtypes in the ovariectomized cynomolgus monkey. Fournal of Clinical Endocrinology and Metabolism 88 655-662.

Krey LC, Butler WR \& Knobil E 1975 Surgical disconnection of the medial basal hypothalamus and pituitary function in the rhesus monkey. I. Gonadotropin secretion. Endocrinology 96 1073-1087.

Latimer VS \& Urbanski HF 2002 Do gonadotropin-releasing hormone II cells express estrogen receptors in the female rhesus monkey? Endocrine Society Abstracts 178-179.

Latimer VS, Rodrigues SM, Garyfallou VT, Kohama SG, White RB, Fernald RD \& Urbanski HF 2000 Two molecular forms of gonadotropin-releasing hormone (GnRH-I and GnRH-II) are 
expressed by two separate populations of cells in the rhesus macaque hypothalamus. Brain Research (Molecular Brain Research) 75 287-292.

Latimer VS, Kohama SG, Garyfallou VT \& Urbanski HF 2001 A developmental increase in the expression of messenger ribonucleic acid encoding a second form of gonadotropin-releasing hormone in the rhesus macaque hypothalamus. Fournal of Clinical Endocrinology and Metabolism 86 324-329.

Lescheid DW, Terasawa E, Abler LA, Urbanski HF, Warby CM, Millar RP \& Sherwood NM 1997 A second form of gonadotropin-releasing hormone $(\mathrm{GnRH})$ with characteristics of chicken GnRH-II is present in the primate brain. Endocrinology $1385618-5629$.

Lovejoy DA, Stell WK \& Sherwood NM 1992 Partial characterization of four forms of immunoreactive gonadotropin-releasing hormone in the brain and terminal nerve of the spiny dogfish (Elasmobranchii; Squalus acanthias). Regulatory Peptides 37 39-48.

Ma YJ, Costa ME \& Ojeda SR 1994 Developmental expression of the genes encoding transforming growth factor alpha and its receptor in the hypothalamus of female rhesus macaques Neuroendocrinology 60 346-359.

Mitsushima D, Hei DL \& Terasawa E 1994 Gamma-aminobutyric acid is an inhibitory neurotransmitter restricting the release of luteinizing hormone-releasing hormone before the onset of puberty. PNAS 91 395-399.

Miyamoto K, Hasegawa Y, Nomura M, Igarashi M, Kangawa K \& Matsuo H 1984 Identification of the second gonadotropin-releasing hormone in chicken hypothalamus: evidence that gonadotropin secretion is probably controlled by two distinct gonadotropin-releasing hormones in avian species PNAS $813874-3878$.

Montero M, Le Belle N, King JA, Millar RP \& Dufour S 1995 Differential regulation of the two forms of gonadotropin-releasing hormone ( $\mathrm{mGnRH}$ and $\mathrm{cGnRH}-\mathrm{II})$ by sex steroids in the European female silver eel (Anguilla anguilla). Neuroendocrinology 61 525-535.

Mosselman S, Polman J \& Dijkema R 1996 ER beta: identification and characterization of a novel human estrogen receptor. FEBS Letters 392 49-53.

Muske LE \& Moore FL 1990 Ontogeny of immunoreactive gonadotropin-releasing hormone neuronal systems in amphibians. Brain Research 534 177-187.

Nakai Y, Plant TM, Hess DL, Keogh EJ \& Knobil E 1978 On the sites of the negative and positive feedback actions of estradiol in the control of gonadotropin secretion in the rhesus monkey. Endocrinology 102 1008-1014.

Okuzawa K, Amano M, Kobayashi M, Aida K, Hanyu I, Hasegawa Y \& Miyamoto K 1990 Differences in salmon GnRH and chicken GnRH-II contents in discrete brain areas of male and female rainbow trout according to age and stage of maturity. General and Comparative Endocrinology 80 116-126.

Ordog T, Goldsmith JR, Chen MD, Connaughton MA, Hotchkiss J \& Knobil E 1998 On the mechanism of the positive feedback action of estradiol on luteinizing hormone secretion in the rhesus monkey. Fournal of Clinical Endocrinology and Metabolism $\mathbf{8 3}$ 4047-4053.

Parhar IS, Soga T \& Sakuma Y 1996 In situ hybridization for two differentially expressed GnRH genes following estrogen and triiodothyronin treatment in the brains of juvenile tilapia (cichlid). Neuroscience Letters 218 135-138.

Pau KY, Berria M, Hess DL \& Spies HG 1993 Preovulatory gonadotropin-releasing hormone surge in ovarian-intact rhesus macaques. Endocrinology 133 1650-1656.
Plant TM 2001 Neurobiological bases underlying the control of the onset of puberty in the rhesus monkey: a representative higher primate. Frontiers in Neuroendocrinology 22 107-139.

Plant TM, Krey LC, Moossy J, McCormack JT, Hess DL \& Knobil E 1978 The arcuate nucleus and the control of gonadotropin and prolactin secretion in the female rhesus monkey (Macaca mulatta). Endocrinology 102 52-62.

Powell RC, Millar RP \& King JA 1986 Diverse molecular forms of gonadotropin-releasing hormone in an elasmobranch and a teleost fish. General and Comparative Endocrinology 63 77-85.

Rance NE \& Uswandi SV 1996 Gonadotropin-releasing hormone gene expression is increased in the medial basal hypothalamus of postmenopausal women. Journal of Clinical Endocrinology and Metabolism 81 3540-3546.

Rozenboim I, Silsby JL, Tabibzadeh C, Pitts GR, Youngren OM \& El Halawani ME 1993 Hypothalamic and posterior pituitary content of vasoactive intestinal peptide and gonadotropin-releasing hormone I and II in the turkey hen. Biology of Reproduction 49 622-626.

Russell KS, Haynes MP, Sinha D, Clerisme E \& Bender JR 2000 Human vascular endothelial cells contain membrane binding sites for estradiol, which mediate rapid intracellular signaling. PNAS 97 5930-5935.

Saunders PT, Millar MR, Williams K, Macpherson S, Harkiss D, Anderson RA, Orr B, Groome NP, Scobie G \& Fraser HM 2000 Differential expression of estrogen receptor-alpha and -beta and androgen receptor in the ovaries of marmosets and humans. Biology of Reproduction 63 1098-1105.

Siler-Khodr TM \& Grayson M 2001 Action of chicken II GnRH on the human placenta. Fournal of Clinical Endocrinology and Metabolism 86 804-810.

Spies HG \& Norman RL 1975 Interaction of estradiol and LHRH on LH release in rhesus females: evidence for a neural site of action. Endocrinology 97 685-692.

Spies HG, Norman RL, Quadri SK \& Clifton DK 1977 Effects of estradiol-17 $\beta$ on the induction of gonadotropin release by electrical stimulation of the hypothalamus in rhesus monkeys. Endocrinology $100314-324$.

Tsai P-S \& Licht P 1993 Differential distribution of chicken-I and chicken-II GnRH in the turtle brain. Peptides 14 221-226.

Urbanski HF, White RB, Fernald RD, Kohama SG, Garyfallou VT \& Densmore VS 1999 Regional expression of mRNA encoding a second form of 23 gonadotropin-releasing hormone in the macaque brain. Endocrinology 140 1945-1948.

Walsh JP \& Clarke IJ 1998 Blockade of the oestrogen-induced luteinizing hormone surge in ovariectomized ewes by a highly selective opioid mureceptor agonist: evidence for site of action. Neuroendocrinology 67 164-170.

White RB, Eisen JA, Kasten TL \& Fernald RD 1998 Second gene for gonadotropin-releasing hormone in humans. PNAS 95 305-309.

Witkin JW, Ferin M, Popilskis SJ \& Silverman AJ 1991 Effects of gonadal steroids on the ultrastructure of $\mathrm{GnRH}$ neurons in the rhesus monkey: synaptic input and glial apposition. Endocrinology 129 1083-1092.

Yamaji T, Dierschke DJ, Bhattacharya AN \& Knobil E 1972 The negative feedback control by estradiol and progesterone of LH secretion in the ovariectomized rhesus monkey. Endocrinology 90 771-777.

Yu KL, Sherwood NM \& Peter RE 1988 Differential distribution of two molecular forms of gonadotropin-releasing hormone in discrete brain areas of goldfish (Carassius auratus). Peptides 9 625-630.

Received 20 November 2003 Accepted 5 April 2004 